\title{
Assessment of Potential of Energy Recovery from Municipal Solid Waste of Allahabad City
}

\section{${ }^{\mathrm{T}}$ Vijai Krishna \\ ${ }^{2}$ Sadhana Chaurasia}

\section{${ }^{1}$ Assistant Professor, Institute of Environment and Sustainable Development, Banaras Hindu University, Varanasi, (U.P.), India \\ ${ }^{2}$ Associate Professor, MGCGV Chitrakoot Gramodaya Vishavidyalaya, Chitrakoot (Satna) M.P., India}

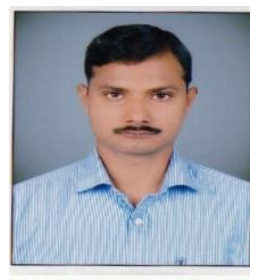

Corresponding author:

Vijai Krishna vicki2050@gmail.com

Received: May 05, 2017

Revised: June 09, 2017

Published: June 30, 2017

\begin{abstract}
Municipal solid waste management is a great environmental, economical, social and urban problem throughout the world. Municipal solid waste management involves the systematic and regular collection, storage, transportation, processing and disposal of the municipal solid waste. Processing involves the sorting of different types of components from the municipal waste like paper, plastic, metal, glass, fabric, biodegradable, inert and other types of components for the purpose of reuse and recycling. Processing also involves methods for energy recovery and thermal treatment like incineration and Pyrolysis. Paper, plastic, metal, glass, inert materials can easily be reused and recycled but the biodegradable waste generally treated further for production of biogas through anaerobic process while for the production of manure through aerobic process. Remaining waste which cannot be treated further goes for the landfilling. For a better municipal solid waste management the processing is favoured method than landfilling. All the waste components which cannot be reused or recycled can be used for the energy recovery. All the components have energy producing capacity after ignition due to their chemical structure. This research paper reveals the potential of energy production from the municipal solid waste of city of Allahabad. The study reveals that the energy content of the municipal solid waste of Allahabad city was 2713.66, 2799.39 and 3294.52 Mwh per day in 2011, 2012 and 2013 respectively.
\end{abstract}

Keywords- Municipal solid waste management, energy recovery, reuse and recycling. 


\section{INTRODUCTION}

According to Municipal solid waste (management and handling rule) 2013 "municipal solid waste" includes the commercial and residential waste generated in municipal or notified areas in either solid or semi-solid form excluding industrial hazardous waste; e-waste and including treated bio-medical waste. Solid waste are all the waste arising from human and animal activities that are normally and that are discarded as useless or unwanted (Peavy et al.1985). The German Waste Act (1972) defined waste as "portable objects that have been abandoned by their owner(s)" or "requiring orderly disposal to protect the public welfare" (Bilitewski et al. 1997). The USA defined waste in the Resource Conservation and Recovery Act (1976), as "any garbage, refuse, sludge from a waste treatment plant, water supply treatment plant, or air pollution control facility and other discarded material, including solid, liquid, semisolid or contained gaseous material resulting from industrial, commercial, mining, and agricultural operations, and from community activities', There are many

\section{MATERIALS AND METHODS}

Study area: The geographical extension of Allahabad city falls from $25^{\circ} 27^{\prime} \mathrm{N}$ to $25.45^{\circ} \mathrm{N}$ and $81^{\circ} 51^{\prime} \mathrm{E}$ to $81.85^{\circ} \mathrm{E}$. The geographical area of the city is about 62 square $\mathrm{km}$. Census data of 2011 states Allahabad city as the $32^{\text {nd }}$ most populous city in India. The population of the city is 975000. The city has poor sex ratio at 807 females per 1000 males. The male and female population of the city are 539,772 and 435,621 . About $10 \%$ population falls between 0-6 years. The literacy rate of the city was $81 \%$ which is better than many other cities of U.P. the population growth rate of the city is $23 \%$. According to 2001 census the average population density is 16,559 persons per sq $\mathrm{k} . \mathrm{m}$. there are 185 slums in the city. About $30 \%$ population of categories of MSW such as food waste, rubbish, commercial waste, institutional waste, street sweeping waste, industrial waste, construction and demolition waste, and sanitation waste. MSW contains recyclables (paper, plastic, glass, metals, etc.), toxic substances (paints, pesticides, used batteries, medicines), compostable organic matter (fruit and vegetable peels, food waste) and soiled waste (blood stained cotton, sanitary napkins, disposable syringes) (Jha et al., 2003; Khan 1994). Increasing waste generation rates due to population growth, changing lifestyles of people, development and consumption of products with materials that are less biodegradable have led to the diverse challenges for municipal solid waste management in various cities of the world. Distinct differences have been identified in literature between municipal solid waste management in developed and developing countries. The current focus is on optimization of waste management practices with a broader goal of resource conservation (Wilson 2007; McDougall et al., 2001).

the city lives in the slums which can be categorised as urban poor category.

Collection of data: Data was collected from primary and secondary sources. In the first phase of the study, sampling sites have been chosen in a way so that the data obtained may represent the composition of the municipal solid waste of the whole city. Four sites have been chosen for this research purpose namely Kareli, Daragnaj, Bakshi Bandh and Jhunsi. Samples of MSW from different sites were collected every month from January 2011 to December 2013 to determine its composition. (The name of the months have been abbreviated as JA, F, M, A, $\mathrm{MY}, \mathrm{J}, \mathrm{JU}, \mathrm{AU}, \mathrm{S}, \mathrm{O}, \mathrm{N}$ and $\mathrm{D}$ in this 
paper). The sampling and analysis of MSW were carried out as per standard procedures described by Peavy et al. (1985). 100 k.g. of Samples were collected from all the four sites including Kareli, Daragnaj, Bakshi Bandh and Jhunsi per month and analysed for its moisture content and the percentage weight of different chosen components (CO) which were paper, plastic, glass, metal, cloth, biodegradable, inert and others waste. (Abbreviated as PA, PL, CL, GL, ME, BD, IN and OT respectively in this paper) Inert waste included crockery, dirt and ash types of material. Other types of waste were those which are difficult to categorize into a particular category of waste like leather, rubber, thermo coal, foam etc. Moisture content (MO) of solid wastes is usually expressed as the weight of moisture per unit weight of wet material. Estimation of the moisture was very necessary as the moisture determines the characteristics of the municipal solid waste, moisture plays an important role in the weight of the solid waste as well as moisture determines the energy content of the municipal solid waste. Estimation of the moisture content was done through the help of procedure given in the Tchobanoglous et al. 1977. The typical moisture content of the different components of waste is given in table: 1. These typical values have been taken as the standard values of the moisture content of the different components during study. During sampling $100 \mathrm{k.g}$. of waste was collected from the sites. Waste is weighted by the general spring balance. Waste material was collected from corners and the middle of the sampling sites. Collected waste was mixed thoroughly so that all the points of sample become homogeneous and all the parts of sample give similar characteristics. Now different components of municipal solid waste have been sorted out by hand like paper, plastic, metal, glass, biodegradable, inert and other wastes. Different components were filled in different polythene bags and tagged. Now every polythene bag was weighted and data was recorded. The average (AVG) total waste per day generated in a year was obtained from the Allahabad Municipal Corporation (AMC) which was 524 ton in 2011, 541 ton in 2012 and 562 ton in 2013. For the energy recovery point of view the percent weight of the inert and other waste has not assessed because their percentage was very low, so only paper, plastic, cloth, glass, metal and biodegradable waste has been analyzed for the following energy parameters:

1. Actual moisture content $=($ Weight of the waste component X Typical Moisture content $)$

100

2. Percent moisture of the sample waste $=($ Actual moisture content X 100)

(Total weight of the waste sample)

3. Actual ash content $=$ (Weight of the waste component $X$ Typical ash content $)$

100

4. Percent ash of the sample waste $=($ Actual ash content X 100)

(Total weight of the waste sample)

3. Energy content $(\mathrm{Kj} / \mathrm{Kg})=($ Total energy/Total mass $)$

4. Energy content on dry basis $(\mathrm{Kj} / \mathrm{Kg})=($ Energy content $\mathrm{X} 100) /(100-$ Percent moisture $)$

5. Energy content on ash free dry basis $(\mathrm{Kj} / \mathrm{Kg})=\quad$ Energy content $\mathrm{X} 100$

(100 - Percent moisture - Percent Ash content)

6. Total energy per day $(\mathrm{Kj} / \mathrm{Kg})=$ Energy content on ash free dry basis $\mathrm{X}$ Total weight of waste in a day

7. Total energy per day $(\mathrm{Gj} / \mathrm{Kg})=$ Total energy per day $(\mathrm{Kj} / \mathrm{Kg}) / 1000000$

8. Total energy per day $(\mathrm{Mwh})=$ Total energy per day $(\mathrm{Gj} / \mathrm{Kg}) \times 0.278$ 
Table-1: Moisture and ash content (\%) of municipal solid waste components (Tchobanoglous et al. 1977)

\begin{tabular}{|c|c|c|c|}
\hline S. No. & Components & Moisture & Ash \\
\hline 1. & Food waste & 70 & 5 \\
\hline 2. & Paper & 6 & 6 \\
\hline 3. & Cardboard & 5 & 5 \\
\hline 4. & Plastic & 2 & 10 \\
\hline 5. & Textile & 10 & 2.5 \\
\hline 6. & Rubber & 2 & 10 \\
\hline 7. & Leather & 10 & 10 \\
\hline 8. & Garden trimmings & 60 & 4.5 \\
\hline 9. & Wood & 20 & 1.5 \\
\hline 10 & Miscellaneous organics & 25 & 5 \\
\hline 11. & Glass & 2 & 0 \\
\hline 12. & Tin cans & 3 & 0 \\
\hline 13. & Nonferrous metal & 2 & 0 \\
\hline 14. & Ferrous metal & 3 & 0 \\
\hline
\end{tabular}

\section{RESULT AND DISCUSSION}

Table-2: Month wise variations among different components of MSW

\begin{tabular}{|c|c|c|c|c|c|c|c|c|c|c|c|c|c|c|}
\hline $\mathrm{CO}$ & YEAR & $\mathbf{J A}$ & $\mathbf{F}$ & $\mathbf{M}$ & $\mathbf{A}$ & MY & $\mathbf{J}$ & $\mathbf{J U}$ & $\mathbf{A U}$ & $\mathbf{S}$ & O & $\mathbf{N}$ & D & AVG \\
\hline & 2011 & 1517 & 15.88 & 1657 & 15.3 & 15.26 & 15.95 & 16.12 & 14.93 & 14.95 & 18.09 & 17.05 & 15.17 & 15.87 \\
\hline \multirow[t]{4}{*}{ PA } & 2012 & 16.19 & 16.69 & 15.41 & 15.32 & 15.33 & 15.44 & 14.57 & 15.89 & 14.81 & 16.36 & 15.74 & 15.31 & 15.59 \\
\hline & 2013 & 13.9 & 14.2 & 14.48 & 13.27 & 13.6 & 15.04 & 14.26 & 13.16 & 14.12 & 14.7 & 14.46 & 14.02 & 14.1 \\
\hline & AVG & 15.09 & 15.59 & 15.49 & 14.63 & 14.73 & 15.48 & 14.98 & 14.66 & 14.63 & 16.38 & 15.75 & 14.83 & 5.19 \\
\hline & 2011 & 16.92 & 16.9 & 17.36 & 18.25 & 17.49 & 17.64 & 18.75 & 16.7 & 16.98 & 16.65 & 17.64 & 16.23 & 17.29 \\
\hline \multirow[t]{4}{*}{ PL } & 2012 & 14.64 & 14.37 & 15.67 & 16.86 & 15.9 & 16.34 & 15.79 & 14.63 & 15.4 & 16.08 & 15.26 & 15.65 & 15.55 \\
\hline & 2013 & 21.33 & 20.27 & 21.88 & 20.88 & 21.47 & 19.83 & 22.57 & 21.92 & 22.07 & 22.94 & 21.76 & 21.16 & 21.51 \\
\hline & AVG & 17.63 & 17.18 & 18.30 & 18.66 & 18.29 & 17.94 & 19.04 & 17.75 & 18.15 & 18.56 & 18.22 & 17.68 & 18.12 \\
\hline & 2011 & 6.66 & 7.17 & 6.88 & 6.38 & 8.29 & 6.75 & 6.29 & 5.76 & 6.29 & 5.47 & 7.17 & 7.83 & 6.74 \\
\hline \multirow[t]{4}{*}{ CL } & 2012 & 9.16 & 9.76 & 9.9 & 8.98 & 9.83 & 9.7 & 9.49 & 8.9 & 9.26 & 10.09 & 10.54 & 9.36 & 9.58 \\
\hline & 2013 & 6.01 & 6.76 & 6.43 & 5.98 & 6.34 & 7.31 & 6.14 & 6.71 & 5.73 & 6.55 & 7.59 & 6.6 & 6.51 \\
\hline & AVG & 7.28 & 7.90 & 7.74 & 7.11 & 8.15 & 7.92 & 7.31 & 7.12 & 7.09 & 7.37 & 8.43 & 7.93 & 7.61 \\
\hline & 2011 & 7.96 & 8.13 & 8.62 & 8.04 & 7.1 & 7.05 & 7.42 & 8.31 & 8.41 & 7.84 & 7.84 & 8.94 & 7.97 \\
\hline \multirow[t]{4}{*}{ GL } & 2012 & 5.87 & 6.86 & 6.28 & 6.02 & 6.49 & 6.29 & 6.67 & 6.72 & 6.87 & 7.44 & 6.31 & 7.65 & 6.62 \\
\hline & 2013 & 6.85 & 6.3 & 5.83 & 6.53 & 6.41 & 5.5 & 5.6 & 6.06 & 6.16 & 5.69 & 5.88 & 6.19 & 6.08 \\
\hline & AVG & 6.89 & 7.10 & 6.91 & 6.86 & 6.67 & 6.28 & 6.56 & 7.03 & 7.15 & 6.99 & 6.68 & 7.59 & 6.89 \\
\hline & 2011 & 6.53 & 7.09 & 6.94 & 7.62 & 6.49 & 6.53 & 7.17 & 6.61 & 6.7 & 7.51 & 6.89 & 6.32 & 6.87 \\
\hline \multirow[t]{4}{*}{ ME } & 2012 & 9.11 & 8.08 & 7.39 & 8.52 & 8.13 & 8.56 & 8.03 & 9.34 & 9 & 9.29 & 9.59 & 8.15 & 8.6 \\
\hline & 2013 & 5.73 & 5.08 & 5.5 & 7.22 & 5.57 & 5.95 & 6.18 & 5.77 & 5.97 & 7.19 & 6.67 & 5.63 & 6.04 \\
\hline & AVG & 7.12 & 6.75 & 6.61 & 7.79 & 6.73 & 7.01 & 7.13 & 7.24 & 7.22 & 8.00 & 7.72 & 6.70 & 7.17 \\
\hline & 2011 & 43.53 & 41.96 & 40.77 & 41.68 & 42.92 & 42.92 & 41.48 & 45.02 & 43.79 & 41.43 & 40.84 & 42.89 & 42.44 \\
\hline \multirow[t]{2}{*}{ BD } & 2012 & 41.68 & 41.19 & 42.37 & 41.32 & 41.21 & 40.77 & 42.36 & 41.61 & 41.43 & 38.13 & 39.64 & 41.21 & 41.08 \\
\hline & 2013 & 42.28 & 43.17 & 42.11 & 41.99 & 42.3 & 42.38 & 41.94 & 42.52 & 42.02 & 39.35 & 40.28 & 42.29 & 41.89 \\
\hline
\end{tabular}


DOI: https://doi.org./10.24163/ijart/2017/2(3):165-171

\begin{tabular}{|c|c|c|c|c|c|c|c|c|c|c|c|c|c|c|}
\hline & AVG & 42.50 & 42.11 & 41.75 & 41.66 & 42.14 & 42.02 & 41.93 & 43.05 & 42.41 & 39.64 & 40.25 & 42.13 & 41.80 \\
\hline & $\mathbf{2 0 1 1}$ & 1.91 & 1.58 & 1.6 & 1.62 & 1.52 & 1.86 & 1.54 & 1.59 & 1.77 & 1.96 & 1.43 & 1.59 & 1.67 \\
\hline IN & $\mathbf{2 0 1 2}$ & 1.89 & 1.56 & 1.54 & 1.48 & 1.65 & 1.46 & 1.53 & 1.36 & 1.59 & 1.31 & 1.31 & 1.29 & 1.5 \\
\hline & $\mathbf{2 0 1 3}$ & 1.95 & 2.03 & 1.62 & 1.92 & 2.22 & 2.06 & 1.84 & 1.68 & 2.07 & 1.97 & 1.86 & 2.13 & 1.95 \\
\hline & AVG & 1.92 & 1.72 & 1.59 & 1.67 & 1.80 & 1.79 & 1.64 & 1.54 & 1.81 & 1.75 & 1.53 & 1.67 & 1.71 \\
\hline & $\mathbf{2 0 1 1}$ & 1.33 & 1.3 & 1.26 & 1.11 & 0.94 & 1.32 & 1.24 & 1.1 & 1.11 & 1.06 & 1.16 & 1.05 & 1.17 \\
\hline OT & $\mathbf{2 0 1 2}$ & 1.48 & 1.49 & 1.46 & 1.49 & 1.47 & 1.46 & 1.56 & 1.55 & 1.64 & 1.3 & 1.62 & 1.39 & 1.49 \\
\hline & $\mathbf{2 0 1 3}$ & 1.95 & 2.19 & 1.65 & 2.22 & 2.11 & 1.95 & 1.73 & 2.18 & 1.87 & 1.62 & 1.52 & 1.98 & 1.92 \\
\hline & AVG & 1.59 & 1.66 & 1.46 & 1.61 & 1.51 & 1.58 & 1.51 & 1.61 & 1.54 & 1.33 & 1.43 & 1.47 & 1.53 \\
\hline & $\mathbf{2 0 1 1}$ & 33.22 & 32.16 & 31.37 & 31.87 & 32.77 & 32.79 & 31.79 & 34.04 & 33.26 & 31.73 & 31.44 & 32.75 & 32.45 \\
\hline MO & $\mathbf{2 0 1 2}$ & 32.26 & 31.98 & 32.72 & 31.95 & 31.94 & 31.62 & 32.68 & 32.17 & 32.07 & 29.86 & 30.97 & 31.86 & 31.84 \\
\hline & $\mathbf{2 0 1 3}$ & 32.41 & 33.14 & 32.25 & 32.26 & 32.49 & 32.63 & 32.16 & 32.64 & 32.21 & 30.43 & 31.11 & 32.49 & 32.17 \\
\hline & AVG & 32.63 & 32.43 & 32.11 & 32.03 & 32.40 & 32.35 & 32.21 & 32.95 & 32.51 & 30.67 & 31.17 & 32.37 & 32.15 \\
\hline
\end{tabular}

Table-3: Potential of energy recovery in 2011

\begin{tabular}{|c|c|c|c|c|c|c|c|c|}
\hline CO & $\begin{array}{c}\text { Weight } \\
\text { (K.g.) }\end{array}$ & $\begin{array}{c}\text { Typical } \\
\text { Percent } \\
\text { moisture }\end{array}$ & $\begin{array}{c}\text { Actual } \\
\text { moisture }\end{array}$ & Dry mass & $\begin{array}{c}\text { Typical } \\
\text { Percent } \\
\text { ash } \\
\text { content }\end{array}$ & $\begin{array}{c}\text { Actual Ash } \\
\text { content }\end{array}$ & $\begin{array}{c}\text { Typical } \\
\text { energy } \\
(\mathbf{K j} / \mathbf{K g})\end{array}$ & $\begin{array}{c}\text { Actual } \\
\text { energy } \\
(\mathbf{K j})\end{array}$ \\
\hline PA & 15.87 & 6 & 0.9522 & 14.9178 & 6 & 0.895068 & 16750 & 265822.5 \\
\hline PL & 17.29 & 2 & 0.3458 & 16.9442 & 10 & 1.69442 & 32600 & 563654 \\
\hline CL & 6.74 & 10 & 0.674 & 6.066 & 2.5 & 0.15165 & 17450 & 117613 \\
\hline GL & 7.97 & 2 & 0.1594 & 7.8106 & 0 & 0 & 150 & 1195.5 \\
\hline ME & 6.87 & 3 & 0.2061 & 6.6639 & 0 & 0 & 700 & 4809 \\
\hline BD & 42.44 & 70 & 29.708 & 12.732 & 5 & 0.6366 & 4650 & 197346 \\
\hline Total & $\mathbf{9 7 . 1 8}$ & - & $\mathbf{3 2 . 0 4 5 5}$ & - & - & $\mathbf{3 . 3 7 7 7 3 8}$ & - & $\mathbf{1 1 5 0 4 4 0}$ \\
\hline
\end{tabular}

Table-4: Potential of energy recovery in 2012

\begin{tabular}{|c|c|c|c|c|c|c|c|c|}
\hline CO & $\begin{array}{c}\text { Weight } \\
\text { (K.g.) }\end{array}$ & $\begin{array}{c}\text { Typical } \\
\text { Percent } \\
\text { moisture }\end{array}$ & $\begin{array}{c}\text { Actual } \\
\text { moisture }\end{array}$ & Dry mass & $\begin{array}{c}\text { Typical } \\
\text { Percent } \\
\text { ash } \\
\text { content }\end{array}$ & $\begin{array}{c}\text { Actual } \\
\text { Ash } \\
\text { content }\end{array}$ & $\begin{array}{c}\text { Typical } \\
\text { energy } \\
(\mathbf{K j} / \mathbf{K g})\end{array}$ & $\begin{array}{c}\text { Actual } \\
\text { energy } \\
(\mathbf{K j})\end{array}$ \\
\hline PA & 15.6 & 6 & 0.936 & 14.664 & 6 & 0.936 & 16750 & 261300 \\
\hline PL & 15.55 & 2 & 0.311 & 15.239 & 10 & 1.555 & 32600 & 506930 \\
\hline CL & 9.58 & 10 & 0.958 & 8.622 & 2.5 & 0.2395 & 17450 & 167171 \\
\hline GL & 6.62 & 2 & 0.1324 & 6.4876 & 0 & 0 & 150 & 993 \\
\hline ME & 8.6 & 3 & 0.258 & 8.342 & 0 & 0 & 700 & 6020 \\
\hline BD & 41.08 & 70 & 28.756 & 12.324 & 5 & 2.054 & 4650 & 191022 \\
\hline Total & $\mathbf{9 7 . 0 3}$ & - & $\mathbf{3 1 . 3 5 1 4}$ & $\mathbf{6 5 . 6 7 8 6}$ & - & $\mathbf{4 . 7 8 4 5}$ & - & $\mathbf{1 1 3 3 4 3 6}$ \\
\hline
\end{tabular}


Table-5: Potential of energy recovery in 2013

\begin{tabular}{|c|c|c|c|c|c|c|c|c|}
\hline CO & $\begin{array}{c}\text { Weight } \\
\text { (K.g.) }\end{array}$ & $\begin{array}{c}\text { Typical } \\
\text { Percent } \\
\text { moisture }\end{array}$ & $\begin{array}{c}\text { Actual } \\
\text { moisture }\end{array}$ & Dry mass & $\begin{array}{c}\text { Typical } \\
\text { Percent } \\
\text { ash } \\
\text { content }\end{array}$ & $\begin{array}{c}\text { Actual } \\
\text { Ash } \\
\text { content }\end{array}$ & $\begin{array}{c}\text { Typical } \\
\text { energy } \\
(\mathbf{K j} / \mathbf{K g})\end{array}$ & $\begin{array}{c}\text { Actual } \\
\text { energy } \\
(\mathbf{K j})\end{array}$ \\
\hline PA & 14.1 & 6 & 0.846 & 13.254 & 6 & 0.846 & 16750 & 236175 \\
\hline PL & 21.51 & 2 & 0.4302 & 21.0798 & 10 & 2.151 & 32600 & 701226 \\
\hline CL & 6.51 & 10 & 0.651 & 5.859 & 2.5 & 0.16275 & 17450 & 113599.5 \\
\hline GL & 6.08 & 2 & 0.1216 & 5.9584 & 0 & 0 & 150 & 912 \\
\hline ME & 6.04 & 3 & 0.1812 & 5.8588 & 0 & 0 & 700 & 4228 \\
\hline BD & 41.89 & 70 & 29.323 & 12.567 & 5 & 2.0945 & 4650 & 194788.5 \\
\hline Total & $\mathbf{9 6 . 1 3}$ & & $\mathbf{3 1 . 5 5 3}$ & $\mathbf{6 4 . 5 7 7}$ & & $\mathbf{5 . 2 5 4 2 5}$ & & $\mathbf{1 2 5 0 9 2 9}$ \\
\hline
\end{tabular}

Table-6: Summary of potential of energy in different years

\begin{tabular}{|c|c|c|c|c|}
\hline S. N. & Energy Parameters & $\mathbf{2 0 1 1}$ & $\mathbf{2 0 1 2}$ & $\mathbf{2 0 1 3}$ \\
\hline $\mathbf{1 .}$ & Total energy $(\mathrm{Kj})$ & 1150440 & 1133436 & 1250929 \\
\hline $\mathbf{2 .}$ & Total Energy $(\mathrm{Kj} / \mathrm{Kg})$ & 11838.24 & 11681.29 & 13012.89 \\
\hline $\mathbf{3 .}$ & $\begin{array}{c}\text { Total Energy on dry basis } \\
(\mathrm{Kj} / \mathrm{Kg})\end{array}$ & 17662.53 & 17257.31 & 19371.12 \\
\hline $\mathbf{4 .}$ & $\begin{array}{c}\text { Total Energy on ash free dry } \\
\text { basis }(\mathrm{Kj} / \mathrm{Kg})\end{array}$ & 18628.57 & 18613.23 & 21086.83 \\
\hline $\mathbf{5 .}$ & Total energy per day $(\mathrm{Kj})$ & 9761369289.41 & 10069758416.66 & 11850800881.62 \\
\hline $\mathbf{6 .}$ & Total energy per day $(\mathrm{Gj})$ & 9761.37 & 10069.76 & 11850.80 \\
\hline $\mathbf{7 .}$ & Total energy per day $(\mathrm{Mwh})$ & 2713.66 & 2799.39 & 3294.52 \\
\hline
\end{tabular}

The results indicate that there were a potential of production of 2713.66, 2799.39 and 3294.52 Mwh in years 2011, 2012 and 2013 respectively. The results show that as the amount of the waste increases the potential of energy recovery also increases. The amount of energy recovery depends upon the percent of the combustible materials present in the waste. The energy recovery directly proportional to the percent of the combustible materials present in the waste.

\section{CONCLUSION}

This investigation explores that there is huge potential of energy recovery from the municipal solid waste generates in the city of Allahabad. The potential of energy recovery was 2713.66, 2799.39 and 3294.52 Mwh per day in 2011, 2012 and 2013 respectively from municipal solid waste. This huge amount of energy which can contribute significantly in the power supply for the city and into the regional or national power grid. The method of energy recovery may be different like combustion, gasification, anaerobic digestion etc. the 
extent of energy recovery will depend not only on the composition of the waste but also on the method of energy recovery because the efficiency of different methods is different. A city administrator should use the suitable method according to the location, climate, finance, experts, composition, and need etc. It is the need

\section{REFERENCES}

Bilitewski B., Ha“rdtle G., Marek K., Weissbach A., Boeddicker H. (1997) Waste management. Springer-Verlag, Berlin, Heidelberg, Germany.

Jha M.K., Sondhi O.A.K., Pansare M. (2003) Solid waste management - a case study. Indian Journal of Environmental Protection 23 (10): 1153-1160.

Khan R. R. (1994) Environmental management of municipal solid wastes. Indian Journal of Environmental Protection 14 (1): 26-30. of the time to not to dispose all the waste but before that there should be efforts to utilize maximum possible amount of waste for the energy recovery. Most of the cities of India also have approximately same type of waste composition, so these cities can also recover energy from municipal solid

waste.

McDougall F., White P., Franke M., Hindle P. (2001) Integrated Waste Management: A Life Cycle Inventory, second ed. Blackwell Science, Oxford, UK, ISBN: 0632058897 (03/11208).

Peavy H.S., Rawe D.R., Tchobanoglous G. (1985). Environmental engineering, McGraw-Hill Book Company, Singapore.

Wilson D.C. (2007) Development drivers for waste management. Waste Management and Research 25:198-207. 